\title{
The Practice of Bridging the Belt and Road Initiative and the 2030 Sustainable Development Goals
}

\author{
The Case of SDG11 Sustainable Cities
}

Yang ZHAO, Bartlett School of Planning, University College London, UK

\begin{abstract}
In 2013, China proposed the Belt and Road Initiative (BRI), a Chinese solution to sustainable development. Based on the original BRI, the emphasis on green and sustainability has become $a$ new trend in recent years because of environmental concerns, especially climate change. In this context, the idea of promoting the BRI to connect the 2030 Sustainable Development Goals (SDGs), integrating regional infrastructure projects with the international sustainable development agenda, and realizing the integration of sustainable development concepts and practices have become the main focus of BRI. As the field to conduct sustainable-related activities and actors for growth, the role of cities has been highlighted in BRI in this process. However, less attention has been paid to this aspect. This paper aims to explore current attempts to achieve sustainable urban development in the background of bridging BRI and SDGs. This paper draws on the theories of urban sustainability to explain the role and main issues of sustainable urban development in the current sustainable development agenda based on the practice of SDG11: Make cities and human settlements inclusive, safe, resilient, and sustainable. The paper explains the background, implementation status, and development trends of BRI and SDG in this area. This paper argues that related practices of achieving urban sustainability are underway as a solution for developing countries. Since the outbreak of COVID-19, China has introduced more policies and experiments to enhance sustainable urban development, testing to apply successful experience to the transformational development of the BRI.
\end{abstract}

\section{Keywords}

Belt and Road Initiative; 2030 Sustainable Development Goals; Urban Sustainability

\section{Introduction}

The Belt and Road Initiative is a China-led effort to promote economic development and inter-regional connectivity in over 115 countries, which is the second phase of China's 'Going out' policy and the most extensive infrastructure construction program worldwide (Armony and Strauss, 2012; Kirchherr et al. 2018; Zhai, 2018). According to statistics from the Chinese Ministry of Commerce (2020), China's cumulative total trade in goods with countries along the BRI exceeded US\$7.8 trillion, direct investment in countries along the route exceeded US\$110 billion, and new contracts for contracted projects amounted to nearly US\$800 billion. In the past several years, most BRI projects concentrated on infrastructure construction and energy exploitation in Asia (Yu, 2017; Renwick et al., 2018). However, such large-scale projects come with significant environmental challenges. China has come under great criticism for its funding of carbon-intensive projects under the BRI, leading to the unsustainable mode of 
product and serious concerns. These could, in turn, seriously undermine the ability of many countries to meet their targets under the UN 2030 Agenda for Sustainable Development. The story of the green economy has become an inevitable choice in the critical period of economic transformation.

Considering both international and domestic changes, Chinese President Xi Jinping called for a 'green, healthy, intelligent, and peaceful' BRI in 2016. In 2017, the Chinese government issued an ecological and environmental cooperation plan and a statement on vision and action in energy development in the Belt and Road. In the same year, President Xi proposed the specific initiative to build a green BRI at the First Belt and Road Forum for International Cooperation. More importantly, this new initiative emphasizes aligning with the 2030 Agenda for Sustainable Development and Sustainable Development Goals (SDGs), primarily environmental targets, to promote green and low-carbon construction and enhance cooperation in ecological and environmental protection.

Cities have dominated the pace of human civilization since the industrial revolution. Although global cities cover less than $3 \%$ of the global surface, urban areas account for $71 \%$ of global carbon emissions and consume $80 \%$ of the world's resources for corresponding production activities (IPCC, 2014). Urbanization poses a huge challenge to global ecological and environmental protection and profoundly affecting the process of global sustainable development. Facing the above issues, the SDGs explicitly responded with programmatic guidance for urban sustainability, i.e., SDG 11: Make cities and human settlements inclusive, safe, resilient, and sustainable. The goal is dedicated to making cities and human settlements inclusive, safe, resilient and sustainable, hoping that the cities of the future will provide opportunities for all and enable access to essential services, energy, housing, transportation, and more for all.

This paper attempts to study the practice of the BRI concerning the SDGs from the perspective of SDG11 and to answer the following questions: Why is it necessary to bridge the BRI with the SDGs? What are the current attempts in the area of SDG11, especially under the Covid-19? Firstly, this paper will review the literature related to sustainable concerns brought by BRI in the past several years. Then, this paper will examine the relationship between the BRI and SDGs. Next, this paper will analyse the current attempts in the area of SDG11 from three perspectives. This paper clearly shows that urban sustainability has already achieved initial practice and results in connecting the BRI and the SDGs. It will be strengthened under the Covid-19, considering the importance of urban sustainability in the BRI and the SDGs.

\section{Literature Review}

Sustainable development is defined as a development that meets the needs of the present without compromising the ability of future generations to meet their own needs (Pezzey, 1992). Sustainable urban development is closely linked to sustainable development. The concept of sustainable urban development originated in the 1972 Human Environment Action Plan for planning and managing human communities. The term "sustainable cities" was first introduced in 1966 at the second United Nations Conference on Human Settlements. Since then, sustainable urban development has been mentioned many times. When it comes to the definition of this concept, sustainable urban development is an approach to development based on respect for natural patterns and rules, a model of urban development dedicated to improving the quality of urban life, including ecological, cultural, political, institutional, social and economic aspects, instead of leaving burdens on future generations. The city's development is perpetuated in the economic, environmental, and social spheres (Nijkamp and Opschoor, 1995).

Currently, sustainable development has become an essential concern of the BRI.

First, this is because the current development model of the BRI is not reasonable, and many projects have brought hidden dangers to the economy and environment of the countries along the route (Weng, 2016). 
Some researchers believe that BRI still faces significant challenges in achieving a sustainable approach and negative environmental impacts accordingly. Many outside China have focused on creating unsustainable indebtedness in the recipient countries, the lack of transparent decision-making around projects, and harm to the local and global environment (Parton, 2018; Balding, 2018; Huang, 2016). According to the classification of risks reported by World Bank report (2019), environmental risks of BRI can be divided into direct and indirect risks. As for direct risks, most BRI infrastructure projects pass through fragile eco regions and key biodiversity areas (KBAs). The problems of habitat loss, pollution, effects on wildlife, and climate change are quite inevitable. For example, Central Asian rangelands are carbon sinks of global importance, and some concerned that increasing BRI-facilitated industrial activity will affect regional climate (Renwick et al.,2018), but these are still poorly quantified. In terms of indirect risks, concerns of land-use change and deforestation have been raised. What is worse, Chinese projects are predominantly located in poorer nations with weak environmental regulations and controls, which lack the corresponding regulation. Therefore, the long-term consequence will be more serious. For example, the promotion of BRI fossil fuel investments (especially coal plants) could lock host countries into fossil fuel dependency for the coming decades and hamper them from reaching their nationally determined contribution carbon targets as established under the Paris Agreement on Climate Change (Gallagher and Qi 2018; Zhou and Esteban, 2018).

Second, achieving a sustainable development model for the BRI is important for its transformation and upgrading. Different scholars have put forward their opinions and proposals on how to carry out sustainable upgrading. In the case of infrastructure, projects are more likely to achieve synergies and economies of scale across the supply chain. They can therefore be used to promote more sustainable management (Tolipoy, 2018). Zheng (2015) emphasizes that the Belt and Road Initiative breaks the established national strategies that emphasize economy over culture, tourism, and talent and strengthens the coordination between government and market allocation. Another category is to analyze and seek solutions to a specific aspect of the BRI construction from the information technology level, such as the choice of models in infrastructure construction, the construction of investment and financing cooperation mechanisms, and the optimal organization of transportation (Liu, 2015). Chinese economists have attempted to model economic variables and national-level environmental indicators for BRI countries (Li and Zhang, 2017; Cheng and Tu, 2015). However, data is often lacking for most BRI routes.

Based on the requirements of sustainable development and environmental threats along the BBRI, many studies have attempted to find solutions, such as emphasizing the difference between arid and semi-arid regions at the geographic level (Li et al., 2016), emphasizing environmental monitoring in the context of the BRI (Liu, 2018), and greening the setting of the BRI itself (Guo and Wang, 2017). In recent years, many domestic and international communities have repeatedly called for the alignment of the BRI and the 2030 SDGs. Cao (2016) argues that the docking of the two is conducive to enhancing trust between China and countries along the route, strengthening the international attractiveness of the Belt and Road Initiative, and enhancing China's participation in South-South cooperation. Some scholars look at the relevance of the two and their prospects from a specific region or a theoretical perspective (Li and Zhu, 2019; Peng, 2017). Li and Zhu (2019) emphasize that the BRI is aligned with the 2030 Agenda and that the combination of the two can bring new opportunities for implementing this agenda in the LAC region.

Generally, most scholars believe that the BRI will effectively promote the implementation of the 2030 SDGs. Integrating the SDGs into the Belt and Road project is a natural choice to promote the BRI. The integration of SDGs in the BRI projects is an inevitable choice for greening the BRI. However, most of the current studies on both are based on macro perspectives, and there is a lack of systematic interpretation and discussion on the interpretation and promotion of specific goals, especially on the connotation and path of sustainable urban development in the docking SDG11, as well as a lack of targeted case studies on this issue. 


\section{Why Bridging the BRI with the 2030 SDGs?}

The alignment of the Belt and Road Initiative with the 2030 SDGs is an indispensable condition and element to promote their respective development and the sustainable development of developing countries worldwide.

The first official guidance for the BRI 2015 Vision and actions on jointly building Belt and Road (the "Vision and Actions") stated that "we should promote ecological progress in investment and trade, increase cooperation in protecting the ecological environment, preserving biodiversity and combating climate change, and join hands to make the Silk Road an environmentally friendly road" (BRF, 2017). The emphasis on sustainable and green development is an essential prerequisite for the transformation and upgrading of the BRI and is also the basis for the wider recognition and support of the international community for the Belt and Road Initiative.

For the SDGs, the BRI provides an opportunity and entry point for the implementation of the goals. 2030 SDGs provide clear and broad goals for global sustainable development, but the problem lies in the lack of detailed implementation paths and means for the broad goals. In this sense, the BRI provides an opportunity and entry point for the 2030 SDGs to advance their realization. At the same time, one of the problems with the 2030 SDGs is the lack of close linkages among the goals, which weakens the holistic consideration of sustainable development. The BRI offers the possibility of integrating the goals. Green infrastructure construction, for example, requires promoting eco-friendly public products and environmental protection infrastructure, promoting the development and transfer of environmentally friendly technologies, ensuring the adoption of clean technologies in infrastructure construction, and ultimately forming a complete industrial chain.

In terms of both concepts, the BRI and the SDGs share many similarities in vision, philosophy, and fundamental principles. Both are in line with the Charter of the United Nations, which states "to achieve international cooperation in solving international problems of an economic, social, cultural, or humanitarian character" (Khan and Nolte, 1995), and both aim to promote global sustainable development, win-win cooperation, peace and collaboration, openness and tolerance, mutual understanding and trust. In terms of specific objectives and priorities, the five major cooperation priorities of the BRI, namely policy communication, facility connectivity, trade facilitation, financial integration, and people-to-people contact, are closely linked to the 17 specific development goals of the SDGs. Therefore, these two international initiatives have similarities and could have cooperation.

\section{The Role of Sustainable Cities in the Bridging process}

Since 2013, the BRI has been developing close economic and trade relations and cooperation with 65 countries and regions along the route. Due to the large number of countries involved and the complex geography of the countries along the route, cities play an important role as hubs for connecting national cooperation projects and communicating with economic zones along the route, with important cities along the route such as Xi'an, Quanzhou, Islamabad, Pakistan, and New Delhi, India taking on a more important role. The understanding of the roles of cities in the BRI has also gone through a process of deepening. Specifically, it can be divided into the following two stages.

\subsection{Phrase 1: Defining Cities' Functions as the Field for Economic Activities (2013-2015)}

At the beginning of the BRI construction, the role of cities along the route received initial attention. At that time, the role of cities was more about improving the concept, expanding the routes, and clarifying the regional division of labor, i.e., the field for economic activities.

In 2015, China clarified the principles, framework ideas, cooperation priorities, and cooperation 
mechanisms for the BRI. In particular, according to the development trends, the BRI needs to rely on the international corridor on land, supported by the central cities along the route, with key economic and trade industrial parks as a platform for cooperation. At the same time, China clarified the comparative advantages of different cities, emphasizing the diversified characteristics of domestic regions to create urban economic clusters. These attempts also corresponded with China's domestic urban development policies. China's National New Urbanization Plan (2014-2020) emphasized the balanced development of urban clusters and small and medium-sized cities in western China. The role of small and medium-sized cities is newly refined in the national strategy, thus forming the linkage between domestic and foreign policies.

Table 1 The specific roles of China's Cities Identified in the First Phase of the BRI

\begin{tabular}{|c|c|c|}
\hline Region & Province/ city & Roles \\
\hline $\begin{array}{l}\text { Northwest and } \\
\text { Northeast China }\end{array}$ & $\begin{array}{l}\text { Province: Xinjiang, } \\
\text { Shaanxi, Gansu, } \\
\text { Ningxia, Qinghai, Inner } \\
\text { Mongolia, Heilongjiang. } \\
\text { City: Xi'an, Lanzhou, } \\
\text { Xining. }\end{array}$ & $\begin{array}{l}\text { Overall roles: transportation hub, trade center, } \\
\text { logistics and cultural center, scientific and } \\
\text { educational center, core area of the BRI. } \\
\text { Ningxia: pilot inland open economy zone. } \\
\text { Inner Mongolia and Heilongjiang: playing the } \\
\text { advantage of the location of Russia and } \\
\text { Mongolia. } \\
\text { Xi'an: a new highland of inland reform and } \\
\text { opening up. }\end{array}$ \\
\hline Southwest China & Guangxi, Yunnan, Tibet & $\begin{array}{l}\text { Overall roles: an international channel for } \\
\text { ASEAN, an important gateway to the organic } \\
\text { convergence of the Maritime BRI and the Silk } \\
\text { Road Economic Belt. } \\
\text { Guangxi: land and sea proximity with ASEAN } \\
\text { countries. } \\
\text { Yunnan: promoting the construction of } \\
\text { international transport channels with } \\
\text { neighboring countries, create a new high } \\
\text { ground for economic cooperation in the } \\
\text { Greater Mekong Subregion, and build a } \\
\text { radiation center for South and Southeast Asia. } \\
\text { Tibet: bordering trade and tourism culture. }\end{array}$ \\
\hline $\begin{array}{lr}\text { Coastal and } \\
\text { Hong Kong, } \\
\text { Macao and } \\
\text { Taiwan regions }\end{array}$ & $\begin{array}{l}\text { Shanghai, Tianjin, } \\
\text { Ningbo-Zhoushan, } \\
\text { Guangzhou, Shenzhen, } \\
\text { Zhanjiang, Shantou, } \\
\text { Qingdao, Yantai, Dalian, } \\
\text { Fuzhou, Xiamen, } \\
\text { Quanzhou, Haikou, } \\
\text { Sanya, etc. }\end{array}$ & $\begin{array}{l}\text { Overall roles: Promoting the construction of } \\
\text { China (Shanghai) Pilot Free Trade Zone and } \\
\text { supporting the construction of Fujian as the } \\
\text { core area of the 21st Century Maritime Silk } \\
\text { Road. } \\
\text { Shanghai, Tianjin, Guangzhou, Shenzhen, } \\
\text { Shantou, etc.: coastal port construction. } \\
\text { Shanghai, Guangzhou: international hub airport }\end{array}$ \\
\hline
\end{tabular}




\begin{tabular}{|l|l|l|}
\hline & & $\begin{array}{l}\text { function. } \\
\text { Shenzhen, Guangzhou, Zhuhai, and Pingtan, } \\
\text { Fujian: Building the Guangdong-Hong Kong- } \\
\text { Macao Greater Bay Area. }\end{array}$ \\
\hline $\begin{array}{l}\text { Inland regions } \\
\text { and cities }\end{array}$ & $\begin{array}{l}\text { Chongqing, Chengdu, } \\
\text { Zhengzhou, Wuhan, } \\
\text { Changsha, Nanchang, } \\
\text { Hefei, } \\
\text { Zhengzhou. }\end{array}$ & $\begin{array}{l}\text { Chongqing, Chengdu, Zhengzhou, Wuhan, } \\
\text { Changsha, Nanchang, Hefei: inland open } \\
\text { economic highlands. } \\
\text { Zhengzhou, Xi'an: constructing aviation ports } \\
\text { and international dry ports, strengthening } \\
\text { customs clearance cooperation between inland } \\
\text { ports and coastal and border ports. }\end{array}$ \\
\hline
\end{tabular}

Source: summarized from the Vision and Action

From the functional division of regions in China in the Vision and Action, it is obvious that most of the expressions are relatively macro in the first phase which need to be improved and refined in practice. For more economically developed regions and provinces, the roles have refined to specific cities. However, in the central and western regions with average or disadvantageous economic levels, the specific roles for each city are not obvious.

\subsection{Phase 2: Sustainable City development as a Growth Point (2016-2020)}

Through the initial construction, the concept of the BRI is becoming more mature. Instead of treating the $\mathrm{BRI}$ as a trade and economic line linking different countries, this is a "multi-level, multi-dimensional and multi-platform network" composed of cities, ports, roads, development zones, and industrial parks along the route. In this sense, cities are the connection points of the BRI. At the same time, since most BRI projects are resource-based exploration and infrastructure projects, environmental protection along the road becomes an essential concern for those environmentally unfriendly projects. The rising awareness of environmental protection and transformation demands behind urban sustainability has become a new growth point of the BRI. This section summarizes three significant attempts in this period.

Promotion of green economic projects. For example, the Chinese government has promoted smart city development and partnerships through bilateral and regional frameworks. The BRI has been operating through the China-ASEAN Summit to promote projects and investments in artificial intelligence, smart cities, Internet of Things, 5G, fiber optic cable construction, fintech, social networks, and blockchain in recent years Southeast Asian countries. Meanwhile, Chinese President Xi Jinping said during the 2017 Belt and Road Forum that "we should adhere to innovation-driven development, strengthen cooperation in frontier areas such as the digital economy, artificial intelligence, nanotechnology and quantum computers, and promote the construction of big data, cloud computing and smart cities to connect into a digital Silk Road in the 21st century. " As part of the ASEAN-China Strategic Partnership Vision 2030 proposed in 2018, China formally committed to support the ASEAN Smart Cities Network (ASCN). The two sides further launched the Smart Cities Cooperation Initiative at the 2019 China-ASEAN Summit, committing to explore cooperation and promote capacity building and knowledge sharing in smart city construction. Some leading projects are listed below. 


\begin{tabular}{|c|c|c|c|c|c|}
\hline Project & Country & Starting year & $\begin{array}{l}\text { Project } \\
\text { Status }\end{array}$ & $\begin{array}{l}\text { Total } \\
\text { Investment }\end{array}$ & Investors \\
\hline Forest City & Malaysia & 2013 & $\begin{array}{l}\text { Phase I } \\
\text { completed in } \\
2019\end{array}$ & $\begin{array}{ll}700 & \text { billion } \\
\text { RMB } & \end{array}$ & $\begin{array}{l}\text { National Garden } \\
\text { Joint Venture } \\
\text { Group }(60 \%)\end{array}$ \\
\hline $\begin{array}{l}\text { New Clark } \\
\text { City }\end{array}$ & Philippines & 2016 & $\begin{array}{l}\text { Contracts } \\
\text { signed in } \\
2019\end{array}$ & 2 billion RMB & $\begin{array}{l}\text { China State } \\
\text { Construction } \\
\text { Engineering } \\
\text { Group }\end{array}$ \\
\hline $\begin{array}{l}\text { New Manila } \\
\text { Bay City, } \\
\text { Manila }\end{array}$ & Philippines & 2017 & $\begin{array}{l}\text { Contracts } \\
\text { signed in } \\
2019\end{array}$ & $\begin{array}{lr}1.48 & \text { billion } \\
\text { RMB } & \text { (Phase } \\
\text { I) } & \end{array}$ & $\begin{array}{l}\text { China- } \\
\text { Philippines } \\
\text { Development } \\
\text { Group }\end{array}$ \\
\hline $\begin{array}{l}\text { New Yangon } \\
\text { City }\end{array}$ & Malaysia & 2020 & $\begin{array}{l}\text { Initial } \\
\text { planning } \\
\text { completed }\end{array}$ & / & $\begin{array}{l}\text { China } \\
\text { Communications } \\
\text { Construction } \\
\text { Group }\end{array}$ \\
\hline
\end{tabular}

Source: summarized from Internet

The standardization of the project construction has been highlighted. In December 2016, 19 global enterprises in energy, transportation, manufacturing, and environment jointly launched the Initiative on Corporate Environmental Responsibility to Build a Green Belt and Road. While undertaking the projects, these enterprises would be asked to follow strict environmental rules, aiming to avoid negative environmental influence and promote the sustainable development of the host cities. More importantly, realizing the green economic development of the cities, especially satisfying the requirements of SDG11, has been stressed. According to a survey of 535 enterprises in the 2019 Chinese BRI Private Enterprises Sustainable Development Report, 358 enterprises were willing to work for their hosts to implement SDG11 sustainable cities, and 90 Chinese private enterprises were carrying out relevant practices.

Platform-building for cooperation. Due to the vast differences in economic development among different countries, the current practice of SDG11 in countries along the BRI inevitably has varying levels. At the same time, many BRI projects are bilateral cooperation projects between China and other individual countries (Huang, 2016), which to a certain extent weakens the scale benefits brought by multi-city cooperation. However, SDG 11 calls for comprehensive and participatory approaches to address cityrelated sustainable issues, especially among developing countries. Therefore, since 2015 , several cityaimed platforms have been established for multilateral cooperation. In this sense, cooperation platforms to promote city-to-city cooperation have become the focus of its development.

In addition to the Belt and Road's platforms, such as the Asian Infrastructure Investment Bank and the Silk Road Fund, and existing cooperation platforms, such as the China-ASEAN cooperation framework, a series of platforms have been established to emphasize sustainable urban development.

Five alliances have been established to promote cooperation among cities in the fields of tourism, sustainable development, and urban innovation, including the Belt and Road Cities Tourism Alliance, the Belt and Road Green Development International Alliance, and the Belt and Road Cities Development Alliance. The main objectives of these alliances are in line with SDG11's emphasis on sustainable urban 
development. For example, one of the objectives of the Belt and Road Cities Tourism Alliance is to protect urban heritage and world heritage, which is similarly stated in SDG11 (11.4 Further efforts to protect and safeguard world cultural and natural heritage).

However, due to the relatively late establishment of these alliances, most of them are still in the preliminary stage of agenda-setting, precise positioning, and signing agendas with other countries. Therefore, these platforms still need more funds and guidance to support their functions. What is worse, due to the impact of the Covid-19 epidemic on the global economy, the urban development of many countries has been deeply affected. In this situation, many alliances have difficulty genuinely implementing their mission objectives, which also poses difficulties for subsequent cooperation on sustainable urban development. However, it is worth mentioning that, under the Covid-19 epidemic, virtual meetings and knowledge sharing have become the new way to contact countries. For instance, the Belt and Road Alliance for Sustainable Cities has held several online roundtables to exchange successful experiences dealing with the Covid-19 epidemic and post-Covid 19 economic development.

Table 3 Sustainable City-related Platforms under the BRI

\begin{tabular}{|c|c|c|}
\hline Planform & $\begin{array}{l}\text { Starting } \\
\text { Time }\end{array}$ & Major Goals and Responsibility \\
\hline The BRI Urban Tourism Alliance & 2015 & $\begin{array}{l}\text { Urban heritage conservation, urban } \\
\text { tourism economic development. }\end{array}$ \\
\hline $\begin{array}{l}\text { The BRI Green Development } \\
\text { International Alliance }\end{array}$ & 2017 & $\begin{array}{l}\text { A multilateral cooperation platform for } \\
\text { exchange, cooperation and knowledge } \\
\text { sharing; promoting the experiments of } \\
\text { environmental quality improvement and } \\
\text { green cities; promoting the alignment of } \\
\text { the "Green Belt and Road" with the } 2030 \\
\text { Sustainable Development Goals. }\end{array}$ \\
\hline $\begin{array}{l}\text { The BRI National Urban } \\
\text { Development Alliance }\end{array}$ & 2017 & $\begin{array}{l}\text { Creating city alliances (Belt and Road } \\
\text { Friendship Docking Cities, Belt and Road } \\
\text { International Eco-Cities) to promote urban } \\
\text { science and technology and agricultural } \\
\text { innovation. }\end{array}$ \\
\hline $\begin{array}{l}\text { The BRI International Cities Alliance } \\
\text { for Credit Cooperation }\end{array}$ & 2018 & $\begin{array}{l}\text { Promoting the construction of credit } \\
\text { system in cities along the route }\end{array}$ \\
\hline The BRI Sustainable City Alliance & 2019 & $\begin{array}{l}\text { Promoting inter-city sustainable } \\
\text { development cooperation and urban } \\
\text { development in the post-epidemic era. }\end{array}$ \\
\hline
\end{tabular}

Source: summarized from Internet

Improve sustainable development evaluation indicators. In addition to the expansion of cooperation areas, scientifically measuring the sustainable development level of countries and cities along the route is also one of the important development directions of stressing SDG11. At present, China and other relevant international organizations are committed to building a complete set of evaluation indicators to 
cover the three major areas of urban economy, environment, and society and meet the multiple connotations of urban sustainability.

In 2015, the United Nations Environment Programme (UNEP) and China launched the Sustainable Urban Development and Livable Garden Communities (SUC) Program, which aims to implement the specific objectives of SDG11 in China and other developing countries. In 2018, a more detailed guideline Evaluation Criteria, Management Systems, and Implementation Framework" released. SUC guidelines break down SDG11 into international standards and scientific implementation systems that are operational, measurable, and assessable. Three cities and three communities in China have been selected as pilot zones to find commonalities in urban development.

In China, there are also some related attempts in the area of evaluation indicators-building. For example, the Global Urban Competitiveness Report (2020-2021), developed by the Chinese Academy of Social Sciences and UN-Habitat, measures the progress of SDG11 practices from the perspective of sustainable urban competitiveness and distills the theoretical framework of the core of SDG11 goals in the form of a matrix, i.e., eradicating poverty, protecting the earth, ensuring peace and prosperity, and sustainability.

Table 4 Sustainable Urban Competitiveness Index and SDG11

\begin{tabular}{|l|l|l|l|l|}
\hline Goal & $\begin{array}{l}\text { Poverty eradication } \\
\text { (equity, inclusion, } \\
\text { affordability) }\end{array}$ & $\begin{array}{l}\text { Protecting the } \\
\text { planet } \\
\text { disaster resilience) }\end{array}$ & $\begin{array}{l}\text { Ensuring peace } \\
\text { and prosperity } \\
\text { (security well- } \\
\text { being) }\end{array}$ & $\begin{array}{l}\text { Sustainability } \\
\text { (innovation, } \\
\text { durability) }\end{array}$ \\
\hline SDG 11 & $\begin{array}{l}\text { Ease of access to } \\
\text { indirect } \\
\text { financing; market } \\
\text { productivity; social } \\
\text { equity index }\end{array}$ & $\begin{array}{l}\text { Ecological diversity; } \\
\text { environmental } \\
\text { pollution; natural } \\
\text { disaster index }\end{array}$ & $\begin{array}{l}\text { Ease of } \\
\text { transportation; } \\
\text { social security } \\
\text { index; cost of } \\
\text { living index }\end{array}$ & $\begin{array}{l}\text { Historical and } \\
\text { cultural index }\end{array}$ \\
\hline
\end{tabular}

Source: Global City Competitiveness Report (2020-2021)

\section{Post-epidemic and SDG11}

COVID-19 seriously affects the development of the BRI and projects along the route, which undoubtedly increases the uncertainty of future growth. Taking the infrastructure construction as an example, the infrastructure development index of the BRI countries has slipped from 119 in 2019 to 110. It may even fall to 103 , the lowest level in the past ten years.

In terms of the development of sustainable cities, the epidemic has caused stagnation or even regression in urban economic growth in a short time, even leading to social problems such as the increased social disparity between rich and poor and higher unemployment (Sharifi et al., 2020). This also reveals the problem of aligning the BRI with the 2030 SDG with sustainable cities. First, the current top-level design and institutional arrangements cannot meet the needs of urban sustainability. Many of them are based on platforms sponsored by variable and spontaneous organizations. Therefore, it is difficult to organize effective practices to solve the current problems encountered by countries in the urban field. In addition, due to the epidemic's impact, it is difficult for companies involved in projects along the route to maintain normal financial operations. Many of the projects on the ground and planned usually cannot be carried out, so the emphasis on promoting sustainable urban development through project cooperation may not sustain growth. 
In the long run, to address the various impacts caused by the new epidemic, governments are faced with two choices when formulating economic recovery plans: First, unsustainable development methods, such as energy-consuming development, promote rapid financial data recovery. Second, accelerating the necessary transformation to develop low-carbon, reasonably priced energy and sustainable cities and transportation systems, in line with the 2030 SDGs to create long-term economic and social benefits. After the 2008 financial crisis, the Korean economy rebounded the fastest among OECD countries, primarily because Korea spent the majority (about 69\%) of its stimulus on greening (Guangming Daily, 2020). This case proves that the fundamental way to promote sustainable urban development is to improve each country's green growth and strength.

Taking the epidemic as an opportunity to promote the transformation of the urban economy into an intelligent one with a framework for smart city development is one of the response strategies of countries including China, the United States, and South Korea. For example, South Korea's smart city data center system uses cameras and other sensors to track infected people, an approach that South Korea is one of the few countries that has rapidly reduced infection rates without a complete lockdown (Sonn and Lee, 2020). In addition, it is crucial to restore urban vitality and create a favorable social climate in the post-epidemic era. For example, Chengdu, China, explores urban social construction in the post-epidemic era, emphasizing the vital role of urban lifestyle for urban development. It also highlights promoting urban development from industrial logic back to human logic and from production-oriented to lifeoriented, bringing opportunities for transformation of sustainable urban development.

Overall, the epidemic has brought short-term pain and long-term transformation opportunities for the $\mathrm{BRI}$ and sustainable urban development.

\section{Conclusion}

After years of development, the BRI has become the largest infrastructure project in the world today. Accordingly, China has become more closely integrated into regional and global cooperation. The potential cooperation has brought by this process is enormous; however, the transformational issues has raised are far-reaching. Especially in the context of sustainable development becoming a significant international development trend, it is urgent to realize the "Green Belt and Road" transformation, and promote high-quality cooperation among the countries along the route. Indeed, sustainable urban development is not an essential issue in the BRI. However, cities have a significant influence on the development of human society. In this context, it is of great relevance to explore the relationship between the BRI and the sustainable development of cities.

Sustainable city development provides a path for sustainable development in China and developing countries in general. As the product of social development, the large-scale and profound urbanization of Chinese society has produced complex social problems. Looking at urban issues from sustainable development can provide the most practically meaningful guidance for a series of current Chinese urban issues. With the implementation of a sustainable development strategy in China, realizing it has become a vital policy landing point and an essential element of China's implementation of the sustainable development strategy. In 2020, China proposed "people's city built by the people, people's city for the people", which contains the spirit of achieving sustainable development. In this context, sustainable urban economic, environmental and social development has been integrated into the current urban development strategy. It will become the focus of development in the coming period. In other words, sustainable urban development will play a more critical role in China's future social construction.

From the perspective of current practices, developing countries must face the pressure of population, resources, and environment in their economic development and deal with the relationship between population, resources, environment, and economic development to build a sustainable development 
framework. Environmental pollution, ecological degradation, climate change, and food and energy crises are eating into the ability to developing countries to achieve sustainable development. As the intersection of many development factors, cities can provide a testing ground for developing countries, which deserves to receive more attention.

\section{References}

Armony, A. C. and Strauss, J. C. (2012) 'From going out (zou chuqu) to arriving in (desembarco): Constructing a new field of inquiry in China-Latin America interactions', The China Quarterly, 209, p1-17.

Balding, C. (2018) 'Why democracies are turning against Belt and Road', Foreign Affairs, 24.

Belt and Road Forum for International Cooperation (BRF) (2017) 'Vision and actions on jointly building Belt and Road', 10 April 2017. Available at http://2017.beltandroadforum.org/english/n100/2017/0410/c22-45.html (accessed: 8 September 2021)

Gallagher, K. S., and Qi, Q. (2018) 'Policies governing China's overseas development finance implications for climate change. Center for International Environment and Resource Policy', The Fletcher School, Tufts University, March, (016).

Huang, Y. (2019) 'Environmental risks and opportunities for countries along the Belt and Road: Location choice of China's investment', Journal of Cleaner Production, 211, p14-26.

IPCC. (2014) 'Human settlements, infrastructure, and spatial planning', Climate Change 2014: Mitigation of Climate Change. Contribution of Working Group III to the Fifth Assessment Report of the Intergovernmental Panel on Climate Change. O Edenhofer et al. (eds.). Cambridge and New York: Cambridge University Press.

Khan, D. E., Nolte, G., and Paulus, A. (1995) The charter of the United Nations. B. Simma (Ed.). oup.

Kirchherr, J.W, Repp L, van Santen R, Verweij PA, Hu X, Hall J. (2018) 'Greening the Belt and Road initiative WWF's recommendations for the finance sector', World Wildlife Fund, Gland, Switzerland. Available from https://dspace.library.uu.nl/handle/1874/362894(accessed April 2020).

Li, Y., and Zhu, X. (2019) 'The 2030 agenda for sustainable development and China's belt and road initiative in Latin America and the Caribbean', Sustainability, 11(8), 2297.

MOFCOM (2017). 'The economic and trade cooperation between China and the 'Belt and Road' countries', Ministry of Commerce of the People's Republic of China, Beijing. Available from http://www.mofcom.gov.cn/article/tongjiziliao/dgzz/201512/20151201213367.shtml(accessed April 2020).

Nijkamp, P., and Opschoor, H. (1995) 'Urban Environmental Sustainability: Critical Issues and Policy Measures in a Third world Context', Urban Policies in Third World Countries.

Parton, C. (2018) 'China's looming water crisis', China Dialogue.

Pezzey, J. (1992). 'Sustainable development concepts', World, 1(1), p 45. 
Renwick, N., Gu, J. and Gong, S. (2018) 'The impact of BRI investment in infrastructure on achieving the Sustainable Development Goals', K4D Emerging Issues Report.

Sharifi, A., and Khavarian-Garmsir, A. R. (2020) 'The COVID-19 pandemic: Impacts on cities and major lessons for urban planning, design, and management', Science of the Total Environment, 142391.

Sonn, J. W. and Lee, J. K. (2020) 'The smart city as time-space cartographer in COVID-19 control: the South Korean strategy and democratic control of surveillance technology', Eurasian Geography and Economics, 61(4-5), p482-492.

Tolipoy, F. (2018) 'One belt, one road in Central Asia: Progress, challenges, and implications' In Arduino A, Xue $G$ (eds) Securing the belt and road initiative. Palgrave, Singapore.

Weng, D. L. (2016) 'Discussion on financial support and cooperation risk of "The Belt and Road" construction', Northeast Asia Forum, 10(6), 73-74.

Yu, H. (2017) 'China's Belt and Road Initiative and its implications for Southeast Asia', Asia Policy, 24, p117-122.

$\mathrm{Yu}$, J. (2018) 'The belt and road initiative: domestic interests, bureaucratic politics and the EU-China relations', Asia Europe Journal, 16(3), 223-236.

Zhai, F. (2018) 'China's belt and road initiative: A preliminary quantitative assessment', Journal of Asian Economics, 55, p84-92.

Zhou, W. and Esteban, M. (2018) 'eyond balancing: China's approach towards the Belt and Road Initiative', Journal of Contemporary China, 27(112), 487-501.

曹嘉涵.( 2016) “一一带一路”倡议与 2030 年可持续发展议程的对接”，国际展望，8(03), 37-53+144.

成帅华,涂锋. (2015) “一一带一路”助力全球可持续发展”, 中国经济报告,11, 107-109.

国冬梅,王玉娟. (2017) “绿色“一带一路”建设研究及建议”, 中国环境管理, 9(3), 15-19.

李新武,张丽, 郭华东,傅文学, 鹿琳琳,邱玉宝,王心源,贾根锁.(2016) “丝绸之路经济带”干旱-半干旱区 生态环境全球变化响应的空间认知', 中国科学院院刊, 31(5), 559-566.

马尼希.巴布纳.(2020)后疫情时代的人类可持续发. 光明日报,2020-05-22(12) Available at: https://baijiahao.baidu.com/s?id=1667360803673196134\&wfr=spider\&for=pc (Accessed: 9 September 2021)

郑志来.(2015)“一带一路”战略与区域经济融合发展路径研究”.现代经济探讨, 07,25-28+42. 